\title{
Friction Welding of Aluminium and Aluminium Alloys with Steel
}

\author{
Andrzej Ambroziak, Marcin Korzeniowski, Paweł Kustroń, Marcin Winnicki, \\ Pawel Sokołowski, and Ewa Harapińska
}

Welding Technology Department, Institute of Production Engineering and Automation, Wroclaw University of Technology, 50-370 Wroclaw, Poland

Correspondence should be addressed to Andrzej Ambroziak; andrzej.ambroziak@pwr.wroc.pl

Received 10 December 2013; Revised 12 February 2014; Accepted 11 March 2014; Published 28 April 2014

Academic Editor: Achilles Vairis

Copyright (C) 2014 Andrzej Ambroziak et al. This is an open access article distributed under the Creative Commons Attribution License, which permits unrestricted use, distribution, and reproduction in any medium, provided the original work is properly cited.

\begin{abstract}
The paper presents our actual knowledge and experience in joining dissimilar materials with the use of friction welding method. The joints of aluminium and aluminium alloys with the different types of steel were studied. The structural effects occurring during the welding process were described. The mechanical properties using, for example, (i) microhardness measurements, (ii) tensile tests, (iii) bending tests, and (iv) shearing tests were determined. In order to obtain high-quality joints the influence of different configurations of the process such as (i) changing the geometry of bonding surface, (ii) using the interlayer, or (iii) heat treatment was analyzed. Finally, the issues related to the selection of optimal parameters of friction welding process were also investigated.
\end{abstract}

\section{Introduction}

The family of friction welding processes includes several methods, such as rotary friction welding (RFW), linear friction welding (LFW), and the newest one, friction stir welding (FSW). However, the main principle is always the same-to obtain the joint it is necessary to heat the materials to the plastic-state and with the use of "upsetting force" plastically displace the materials and create the weld. The heat is generated by the friction between two welded components (RFW and LFW) or between components and specially designed tool (FSW). Welding processes are classified as solid-state joining methods because the melting of joined materials does not occur these processes [1-3].

A big attractiveness of these joining methods results from many technical and economic advantages, such as high efficiency and stability of the process or better conditions of occupational safety and health than in the case of traditional welding technologies. However, recently, the most important seems to be the possibility of joining materials with different properties. Due to the fact that in the fusion zone between the two different materials the intermetallic compounds are formed and the joining process of dissimilar materials is often very difficult. To obtain high-quality joint it is necessary to know and analyze phase diagram of the two welded materials. Furthermore, the microstructure and different properties of intermetallic phases, such as crack sensitivity, ductility, and corrosion resistance,, are also very important. There are some additional factors, for example, coefficients of thermal expansion of welded materials and their melting temperatures, the knowledge of which is also necessary in the case of joining dissimilar materials [3-6].

The presented review summarizes our actual knowledge about the friction welding of aluminium and aluminium alloys with different types of steel. This paper describes both authors' research as well as many other studies of scientists dealing with the presented subject.

\section{Results and Discussion}

2.1. Aluminium-Steel. Joining with the welding methods of the pairs of materials, such as aluminium alloys-steel, still brings many problems. Even the analysis of the aluminiumiron dual system leads to the conclusion that sufficiently long time and high temperatures of the process can cause 
the formation of intermetallic phases and can be the reason for brittleness of joints (Figure 1). In the case of welding steel to aluminium, the excessively fragile intermetallic compounds lead to the joint degradation. In the Al-Fe equilibrium system, there is no solubility in a solid phase. Therefore, when using the friction welding the intermetallic phases are formed, despite joining in the solid state. The main component of intermetallic phases, which were created at the border of the steel-aluminium joint, is an $\mathrm{Al}_{3} \mathrm{Fe}$ [7]. When joining pure aluminium with stainless steel, Sundaresan and Murti have reported that the compounds of $\mathrm{Fe}_{2} \mathrm{Al}_{5}$ and $\mathrm{FeAl}_{3}$ had been formed on the joint's surface [8]. Fukumoto et al. [9] have observed that not only compounds of $\mathrm{Fe}_{2} \mathrm{Al}_{5}$ and $\mathrm{FeAl}_{3}$ had been formed on the welding surface, but also the FeAl phase. Seli and coauthors [10] have tried to model the heat distribution during the friction welding of aluminium and structural steel and connect it with the formation of intermetallic phases.

Jessop et al. [11] have shown that in the aluminiumaustenitic steel joints, the intermetallic phases were formed on the joints' boundary. The intermetallic phases had width of $3.0 \mu \mathrm{m}$ and were unevenly distributed over the diameter of the friction surface. Jessop has observed that the highest thickness of the intermetallic phases was present on the surface, in the distance of about half radius from the axis of the sample. The researches on the shear energy of the joints have determined its dependence on the thickness of the intermetallic phases. Therefore, when the thickness of the intermetallic phases was $0.2-1.0 \mu \mathrm{m}$, the shear energy was the highest (about $600 \mathrm{~J}$ ). When the thickness was lower than $0.2 \mu \mathrm{m}$ or was higher than $2 \mu \mathrm{m}$, the shear energy decreased to about $400 \mathrm{~J}$. The author stated that lack of the intermetallic phases probably indicated the unstable joining process, and too high thickness of the fragile intermetallic phases caused the reduction of the shear energy value.

Elliott and Wallach [16] and authors of the elaboration $[7,17]$ have come to similar conclusions. Their researches confirmed that the thickness of the intermetallic phases depends on the friction time and rotational speed, and the highest tensile strength was obtained for a layer's thickness of $1-2 \mu \mathrm{m}$.

Yilbaş et al. [17] have carried out the researches that concern the friction welding of aluminium and steel. For testing, they have used nonalloy carbon steel with a five times higher tensile strength than the tensile strength of aluminium. They have used three different rotational speeds: 2000, 2500, and $2800 \mathrm{~min}^{-1}$, at various parameters of the friction pressure and friction time $(4,7$, and $10 \mathrm{~s})$, similarly as in the research on steel-copper joints. The occurrence of intermetallic phases on the joint's bound has been observed. The researchers concluded that for a good joint, an intermetallic layer, which was generally in the half radius length, with the thickness of $0.1-1 \mu \mathrm{m}$ was acceptable. On the edges, this layer has occurred in minor amounts, while in the middle of the joint it did not occur at all, which was related to the lowest rotational speed in this area. In the joint at the steel side, the hardness has been reduced to $50 \mathrm{HV}$, in the heat affected zone, at a length of $1.5 \mathrm{~mm}$ from the welding surface. The width of the heat affected zone was very small, compared to welding of other materials. The highest stated value of the tensile strength for rotational speed was $2800 \mathrm{~min}^{-1}$ (Figure 2).

The author's own investigations [18], concerning the direct friction welding of aluminium and X10CrNiTi189 steel at process parameters in accordance with Table 1 (parameter no. 1), have shown some satisfactory strength and plastic properties of the investigated joints (Figure 3 ). The tensile strength has reached $107 \mathrm{MPa}$, and the breaking has occurred at the aluminium side, at high distance from the bonding zone. During the bending test, the bending angles of over $120^{\circ}$ have been obtained. Simultaneously, the entire deformation has occurred at the aluminium side (Figure 3(b)). The achieved results have been repeatable, even at two times' lower rotational speed (Table 1). To prevent the formation of intermetallic phases, shorter friction time $(0.5 \mathrm{~s})$ and high pressure during the upsetting phase (134-259 MPa) have been used. However, they have resulted in significant length reduction of the welded elements $(28.7 \mathrm{~mm})$.

2.2. Aluminium Alloys-Austenitic Steel. The results, discussed in the previous chapter, showed that joining of pure aluminium and steel, by friction welding, was possible. In the technique, especially in marine, aviation, and refrigeration industries, the joints of aluminium alloys and chromiumnickel austenitic steel are applicable. The aluminium alloys with magnesium, especially the AlMg3 alloy, are commonly used in industries, where the higher strength properties (comparing to aluminium) are necessary. The alloying additions, which are present in aluminium alloys (especially magnesium), usually aggravate the metallurgical conditions of aluminium bonding [19]. They cause acceleration of the formation of the intermetallic phases at the joint's bound [20], because of the increase of the diffusion coefficient. Compared to aluminium, magnesium is characterized by a higher diffusion coefficient and has significantly lower solubility in iron. For these reasons, on the welding surface of aluminium alloys that include magnesium, the intensive heterodiffusion and reaction-diffusion processes take place and cause the formation of the intermetallic phases.

In the elaboration [21] it was stated that the $\mathrm{Fe}_{2} \mathrm{Al}_{5}$ phase leached while bonding the A6061 aluminium alloy with AISI 304 stainless steel, during the friction welding process, at the contact surface. However, at the surface of bonding pure aluminium and carbon steel, the compounds of $\mathrm{Fe}_{4} \mathrm{Al}_{13}$ and $\mathrm{Fe}_{2} \mathrm{Al}_{5}[9,22]$ have been observed.

Fukumoto et al. in [23, 24], when analysing with a transmission microscope (TEM) the intermetallic phases that occurred at the boundary of austenitic steel (type 304)aluminium alloy series 5052 joints, have reported a formation of amorphous layers in the solid state at high temperatures.

In the dissertation [25], the weldability of various aluminium alloys (series 1050, 2011, 5052, 5056, and $6061 \mathrm{i}$ $7075)$ and S25C unalloyed carbon steel $(0.26 \% \mathrm{C})$ have been investigated. For this purpose different process parameters have been used: friction time of $1-4 \mathrm{~s}$, friction phase pressure of $10-30 \mathrm{MPa}$, and upsetting phase pressure of 10-80 $\mathrm{MPa}$. An identification of phases, which had been formed on the contact surface of the materials, has been carried out, 


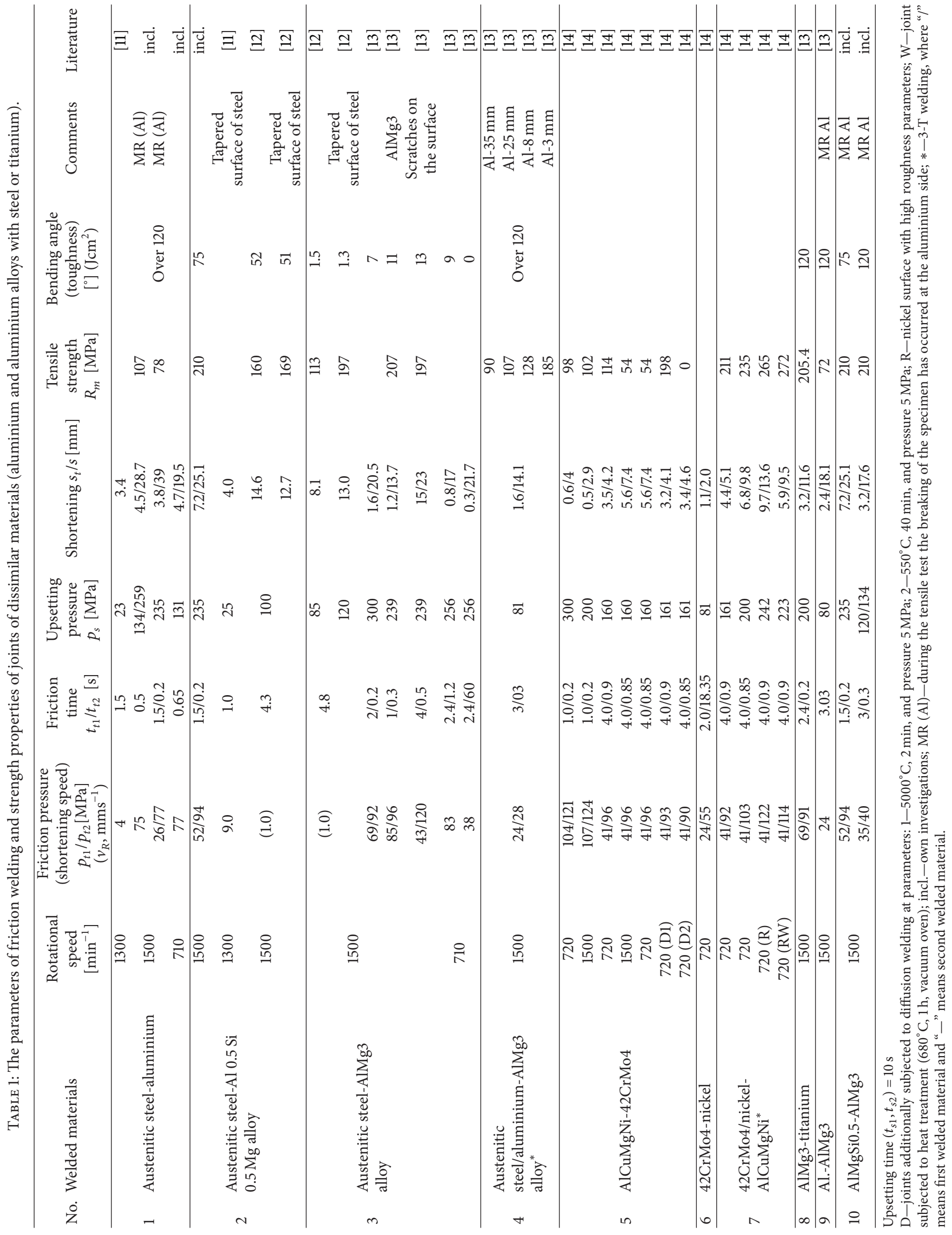




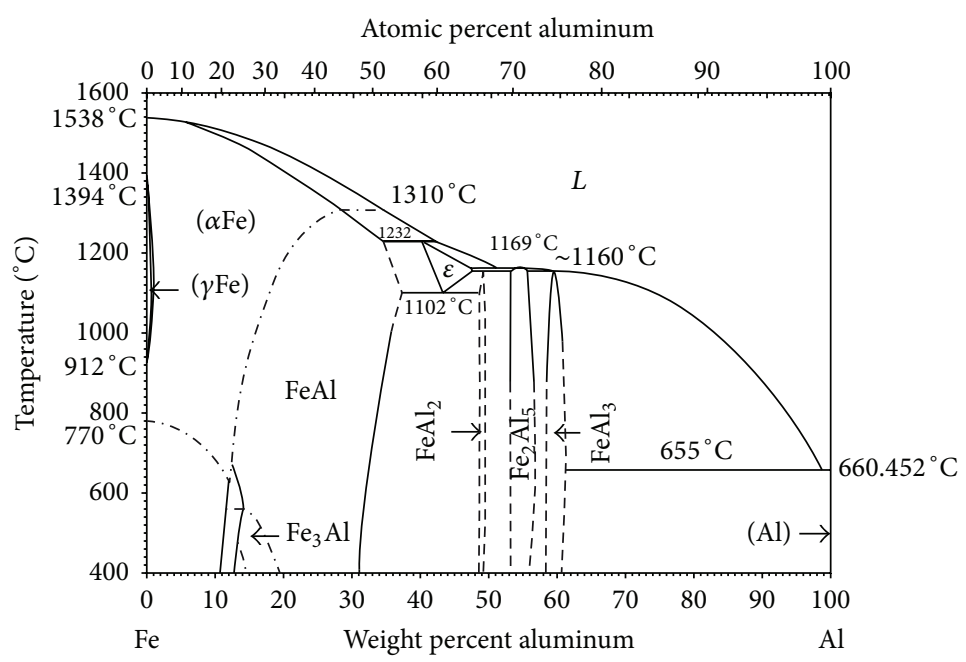

FIGURE 1: Equilibrium diagram for the aluminium-iron system (according to [15]).

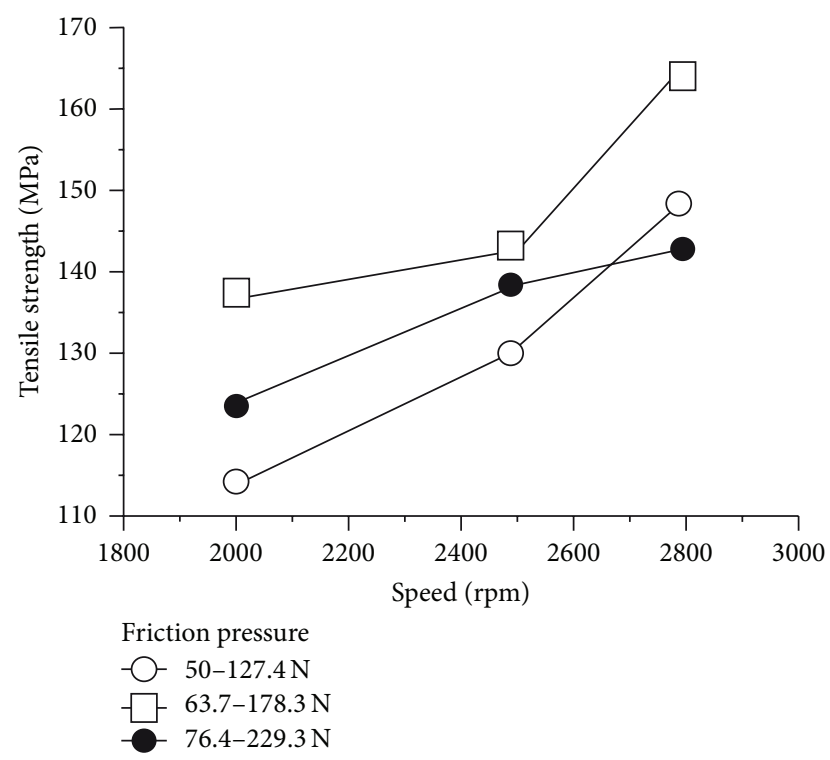

FIGURE 2: Strength properties of the steel-aluminium joint, welded at various parameters (according to [17]).

and the quality of joints has been evaluated on the base of the static tensile test. It has been stated that the joint was characterized by efficient tensile strength, if the width of the diffusion zone (with intermetallic phases) was $0.2-1 \mu \mathrm{m}$. For certain joints, a strength of more than $90 \%$ of the strength of the aluminium alloy (for the following alloys: 1052, 6061, and 6063 ), $50 \%$ (for 5056 alloys) to $26 \%$ for 2011 alloys, and $24 \%$ for 2024 alloys has been achieved. Higher strength values have been stated for the joints of bars, in comparison to tubular joints.

Extensive researches on the friction welding of the A 6061-T6 aluminium alloy with six types of steel, for example, unalloyed steel, toughening steel, and austenitic steel, have been presented by Ochi et al. [7]. The quality of the joints has been evaluated on the base of static tensile test and microhardness measurements. An increase of the joints' strength, together with an increase of the pressure in the friction phase and the shortening (welding time had been controlled with the shortening length), has been stated. The highest strength parameters have reached $280 \mathrm{MPa}$, when the friction pressure has reached $240 \mathrm{MPa}$, and the shortening has been about $16 \mathrm{~mm}$.

The friction welding of aluminium alloys with austenitic steel has been a subject of many elaborations, including the author's one. In most of the publications concerning the welding of steel and aluminium, and its alloys, the test on joints' ductility was usually omitted. The ductility may be evaluated using the technological bending test. Only NA [12] noted the results for the joints investigated in his $\mathrm{PhD}$ dissertation (Table 1).

The issue of plastic properties of friction welded joints of austenitic steel and aluminium alloys, illustrated with an example of AlMgSi0.5 and AlMg3, has been considered in the author's dissertations $[13,14,26]$.

2.2.1. AlMgSi0.5-Austenitic Steel. The friction welded AlMgSi05-X10CrNiTil89 austenitic steel joint, in comparison to the steel-pure aluminium joint, was characterized by higher parameters of tensile strength (about $210 \mathrm{MPa}$ ), but in technological bending test the achieved bending angle has reached about $75^{\circ}$ (Figure 4 ).

Thanks to the microscopic observation it has been possible to find a very narrow diffusion layer on the joint's surface, with a thickness of about $1 \mu \mathrm{m}$ (Figure 5). Other authors have also shown similar results of the tests of joints' strength [18]. However, their values have been lower, probably due to the lower pressure used during the upsetting phase (Table 1).

2.2.2. AlMg3-Austenitic Steel. Until now, it has not been possible to obtain any welded joints of chromium-nickel austenitic steel with AlMg3 aluminium alloy, with sufficient plastic properties for direct joining. The author has been 


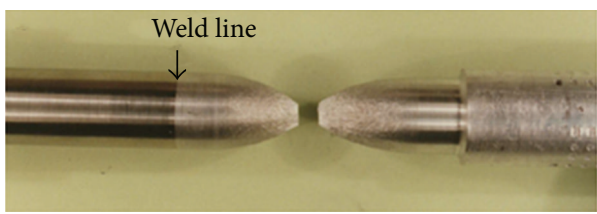

(a)

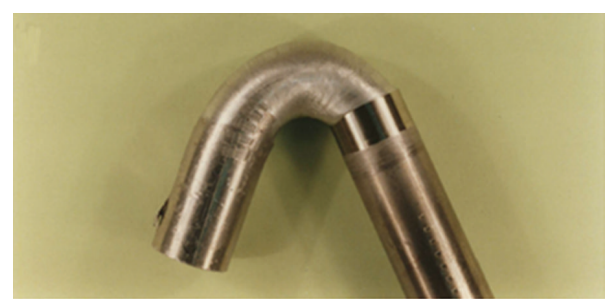

(b)

Figure 3: View of friction welded joints of 99.8 aluminium-X10CrNiTi189 austenitic steel, after the static tensile test (a) and the technological bending test (b).

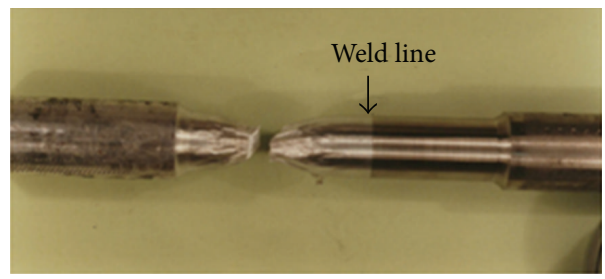

(a)

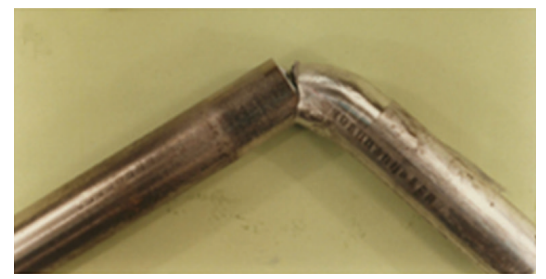

(b)

FIGURE 4: View of friction welded joints of AlMgSi0.5 aluminium alloy-X10CrNiTi189 austenitic steel, after the static tensile test (a) and the technological bending test (b).

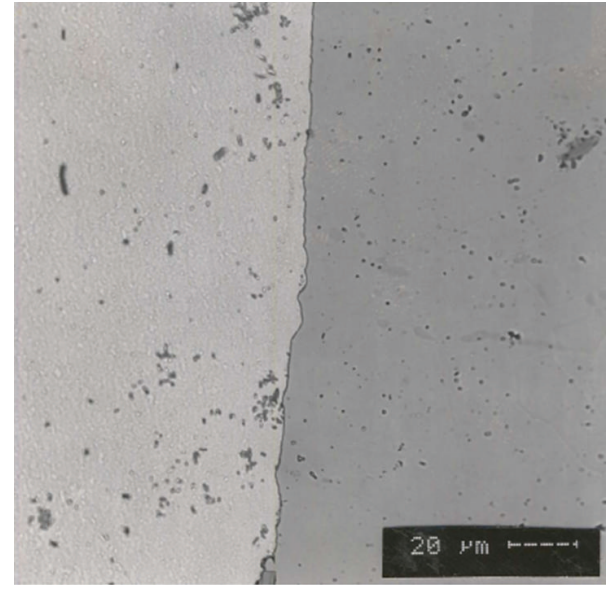

Figure 5: The microstructure in the bonding zone of the friction welded AlMgSi0.5 aluminium alloy-X10CrNiTi189 austenitic steel joint (according to [13]).

conducting some intensive researches on the friction welding of such joints, partly presented in [13].

The friction welded joints of AlMg3-X10CrNiTi189 steel with diameter of $30 \mathrm{~mm}$ had high tensile strength (about $207 \mathrm{MPa}$ ), and the fracture occurred in the base material of AlMg3 alloy (Figure 6(a)). However, in the technological bending tests, bending angles within few degrees have been achieved, with a small dependence on the diameter of the bending mandrel.

The metallographic researches have shown the appearance of the diffusion zone with diameter of 1-6 $\mu \mathrm{m}$, depending on the welding parameters. Despite the short time of the welding process and the high pressure during the upsetting (sample no. 3; Table 1), it has not been possible to fully remove the intermetallic phases from the joint's surface. For the research purposes, a friction welding for a pair of AlMg3 aluminium alloy-X10CrNiTi189 austenitic steel has been conducted, at high welding time (about $62 \mathrm{~s}$ ). In such joint a wide (about $8 \mu \mathrm{m}$ ) diffusion zone, with microhardness reaching up to $1800 \mathrm{HV} 0.005$, has appeared (Figure 7(a)). On the steel side, the microhardness has been equal to $83 \mathrm{HV} 0.005$, and at the intermetallic phases layer it has reached $348 \mathrm{HV} 0.005$. Therefore, at the aluminium alloy side, in a zone adjacent to the intermetallic phases, the increase of microhardness (up to $65 \mathrm{HV} \mathrm{0.005)} \mathrm{has} \mathrm{been}$ reported (microhardness of base material is $58 \mathrm{HV} \mathrm{0.005).}$ The technological bending test of such joint has ended with an immediate crack which has passed the intermetallic layers (Figure 7(b)).

At short welding time $\left(t_{t}=3.6 \mathrm{~s}\right)$ the width of the intermetallic phases has reached $1-2 \mu \mathrm{m}$, but the bending angle has been about $10^{\circ}$. Several attempts to eliminate the intermetallic phases by changing the geometry of bond's surface have been taken (Figure 8).

Figure 9 presents the microstructure of the bonding zone of the friction welded AlMg3 aluminium alloy-X10CrNiTi189 austenitic steel joint, together with a microhardness measurement. The front surface of the steel sample has been prepared with a rough turning (roughness of $R_{z}=150 \mu \mathrm{m}$ ). In Figure 9(a), on the aluminium alloy side, there was a zone with a diameter of $500 \mu \mathrm{m}$, without any microinclusions, and with an increased microhardness, up to $74 \mathrm{HV} 0.015$ (base

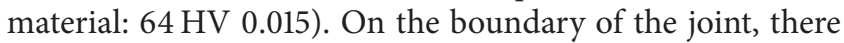
was a narrow (about $1 \mu \mathrm{m}$ ) diffusion zone. The static tensile test has caused a fracture of a sample, on the contact surface, 


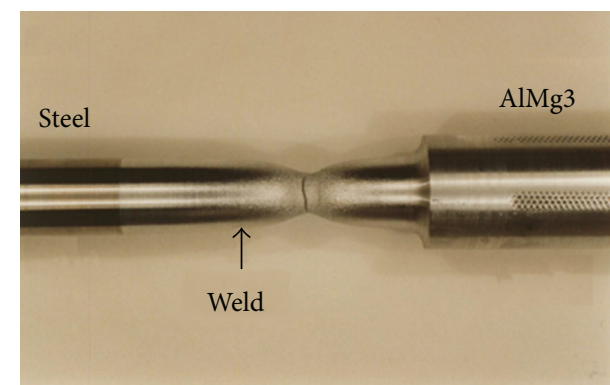

(a)

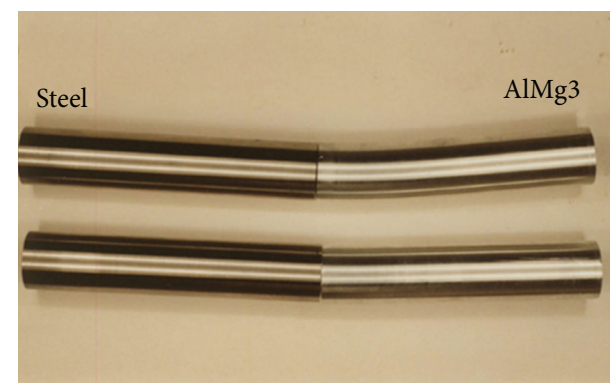

(b)

FIGURE 6: View of friction welded joints of AlMg3 aluminium alloy-X10CrNiTi189 austenitic steel, after the static tensile test (a) and the technological bending test with a bending mandrel with diameter of $20 \mathrm{~mm}$ and $100 \mathrm{~mm}$ (b).

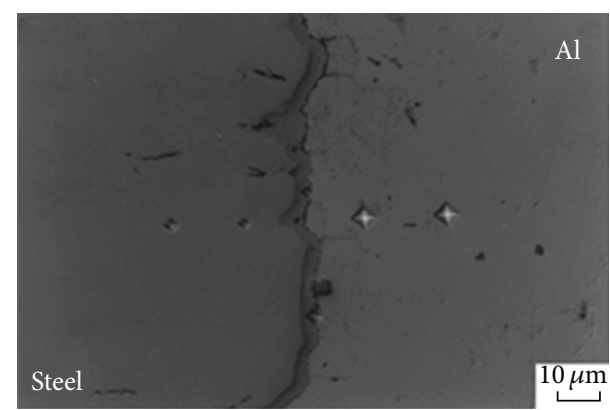

(a)

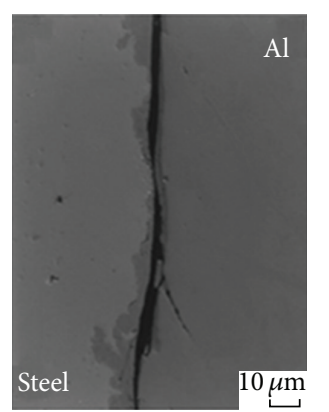

(b)

FIGURE 7: The microstructure in the bonding zone of the friction welded AlMg3 aluminium alloy-X10CrNiTi189 austenitic steel, together with a measurement of microhardness (a) and a bending test (b).
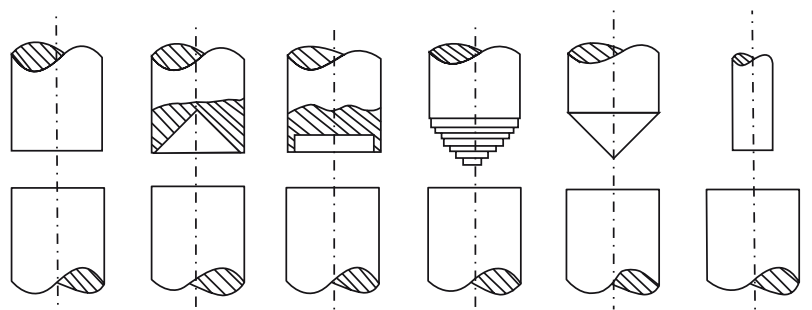

Figure 8: The scheme of the shapes of the friction welded AlMg3 aluminium alloy-X10CrNiTi189 austenitic steel joints' surfaces, used in the investigations [13].

with strength of $197 \mathrm{MPa}$, and the bending angle has been equal to $13^{\circ}$.

Further attempts, including those with the tapered surface of the steel sample (Figure 10), have not caused the elimination of the zones with intermetallic phases on the joint's bound. Maximum bending angles have reached $35^{\circ}$ for a conical shape of the joint.

In Figure 11, a macrostructure and microstructure of the friction welded AlMg3 aluminium alloy, with a diameter of $60 \mathrm{~mm}$, and X10CrNiTi189 austenitic steel, with a diameter of $30 \mathrm{~mm}$ and a substantial roughness of the contact surface on the steel side, are shown. There was a visible flow disruption of AlMg3 material alloy, as a result of macroroughness (Figure 11(a)).

Many attempts have been taken, to form the top surface of steel in the pipe joints with a diameter of $50 \mathrm{~mm}$. Their forming has influenced the various forms of the flash but has not caused an elimination of the intermetallic phases, on the surface of the materials being bonded (Figure 12).

To investigate the influence of the parameters of the friction welding process on the shearing work some researches have been conducted [26]. The joints of AlMg3 aluminium alloy-X10CrNiTi189 austenitic steel (in a shape of bars with $30 \mathrm{~mm}$ diameter) have been formed using three different friction welding parameters carefully selected to ensure various mechanical properties of the joints. It means that there have been attempts to form the joints with various intermetallic phases' thicknesses. So well, the friction time and methods of preparing the steel samples' surfaces have been differentiated. The joints, analysed in the researches, have been formed with friction times of $1.3 \mathrm{~s}$ and $4.5 \mathrm{~s}$ (sample no. 3; Table 1). Due to that, various thicknesses of the layers with intermetallic phases have been obtained, as it can be seen in Figure 13. The top surface of the steel samples has been formed with accurate (sample no. 3: $t_{t}=1.3 \mathrm{~s} ; R_{z}=24 \mu \mathrm{m}$ ) and rough turning (sample no. 3: $t_{t}=4.5 \mathrm{~s} ; R_{z}=152 \mu \mathrm{m}$ ).

While for joints, which have been friction welded with low friction time, there was a continuous narrow diffusion 


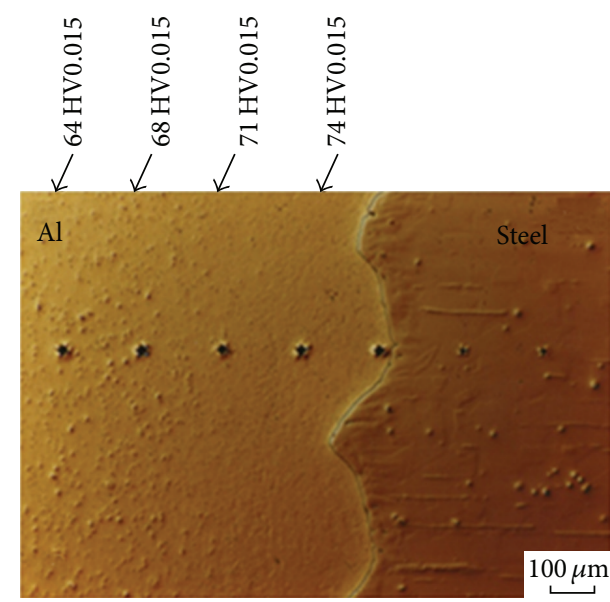

(a)

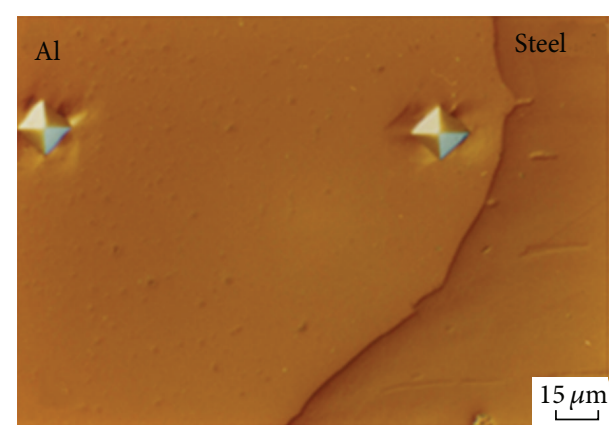

(b)

FIGURE 9: The microstructure in the bonding zone of the friction welded AlMg3 aluminium alloy-X10CrNiTi189 austenitic steel (steel sample with a rough surface of $R_{z}=150 \mu \mathrm{m}$ ) (a) and an enlarged fragment of the microstructure from Figure 9(a) (b).

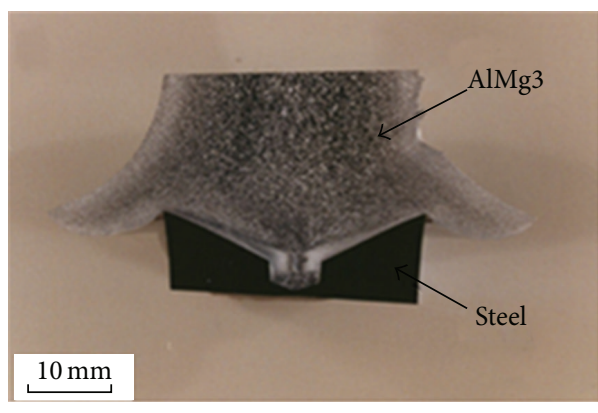

(a)

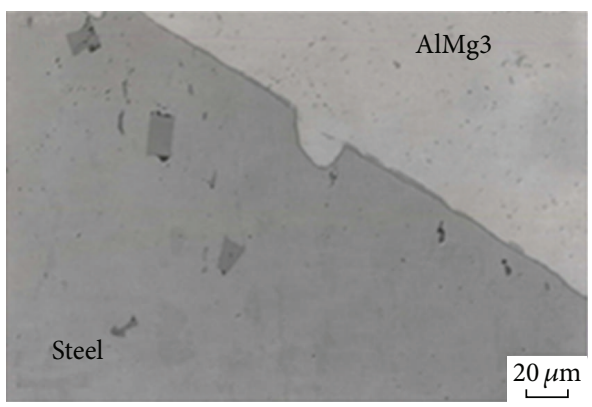

(b)

Figure 10: The macrostructure of the friction welded AlMg3 aluminium alloy-X10CrNiTi189 austenitic steel joint, with a diameter of $30 \mathrm{~mm}$ and a conical shape of the joint (a) and the microstructure of such joint (b).

zone with a diameter of few micrometers (Figure 13(a)); the joints formed at longer friction time were characterized by local thickening of the diffusion layer and discontinuities on the aluminium side (Figures 13(b) and 13(c)).

The results of the maximum loading force, obtained in the shearing test for the investigated joints, are shown in Figure 14, whereas, in Figure 15, the results of shearing work, calculated for two variants of shearing patterns, $F_{t \text { max }}$ and $F_{1}$, are shown. The samples after the shearing test are presented in Figure 16. In the cross-section, depending on the welding parameters, a precipitate of aluminium on the steel side with the amount from 0 to $100 \%$ of the sample's surface, depending on the welding parameters, was visible.

From the previous researches $[27,28]$ it was known that during the friction welding of steel, including austenitic steel with aluminium alloys (with over $2 \%$ of magnesium), the formation of hard and fragile intermetallic phases of $\mathrm{Al}_{13} \mathrm{Fe}_{4}$ type has occurred. Their formation has depended on the diffusion processes that were accelerated by magnesium and their thickness has depended on the welding parameters (especially on the friction time). The joints, analysed in the researches, have been formed with two different friction time parameters, so various thicknesses of the layers with intermetallic phases have occurred. So, for joints that have been friction welded with low friction time, there was a continuous narrow diffusion zone with a diameter of few micrometers (Figure 13(a)) and the joints formed at longer friction time were characterized by local thickening of the diffusion layer and discontinuities on the aluminium side (Figures 13(b) and 13(c)). However, the shearing test has proven a difference of about $5 \%$, for the maximum shearing force between the joints formed with the investigated welding parameters (Figure 14). Wherein, the highest values (average of $107.8 \mathrm{kN}$ ) have been stated for the samples welded at low friction phase time, and the lowest $(102.2 \mathrm{kN})$ values have been obtained for the samples welded at high friction phase time. Therefore, the measurements of the shearing work, carried out for various stages of the test, have shown that there were huge shearing work differences for the analysed joints, and they have depended on the process parameters. If the period to the highest shearing force value $F_{t \max }$ was analysed, then the shearing work was, respectively, for the welding parameters $402 \mathrm{~J} ; 245 \mathrm{~J}$; and $132 \mathrm{~J}$ (Figure 15). When considering the period for the force $F_{1}$, that is, for a force 


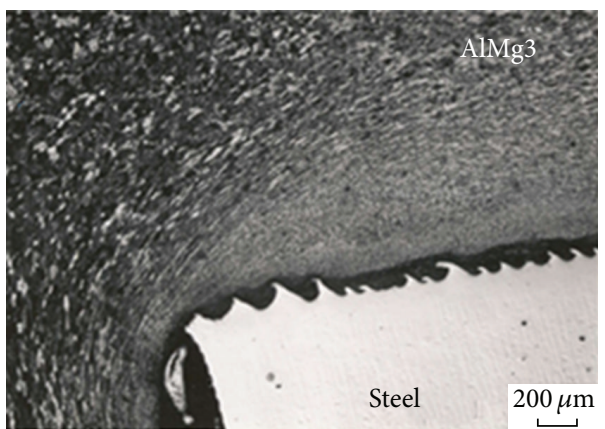

(a)

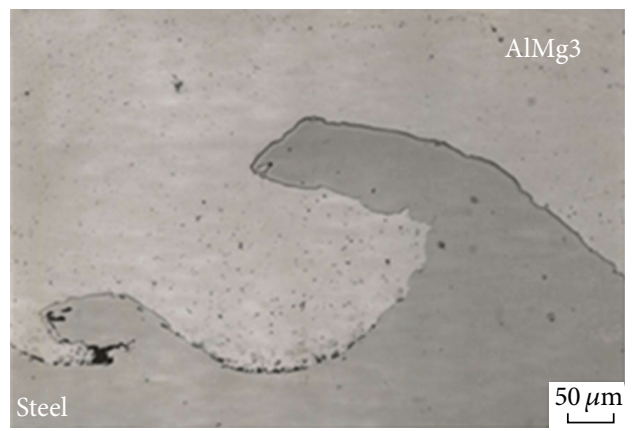

(b)

FIgURE 11: The microstructure of the friction welded AlMg3 aluminium alloy-X10CrNiTi189 austenitic steel joint, with a diameter of 30 mm and substantial roughness of the contact surface (a) and the microstructure of such joint (b).

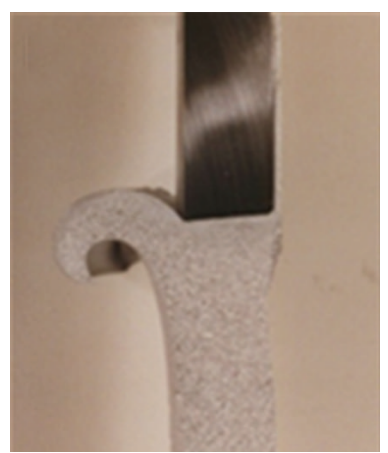

(a)

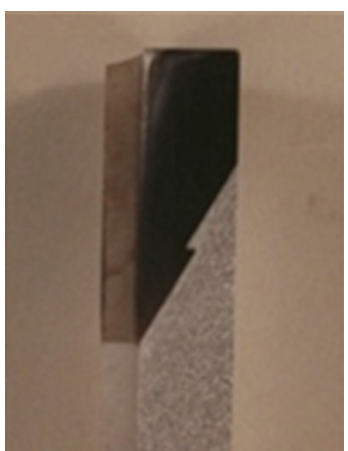

(b)

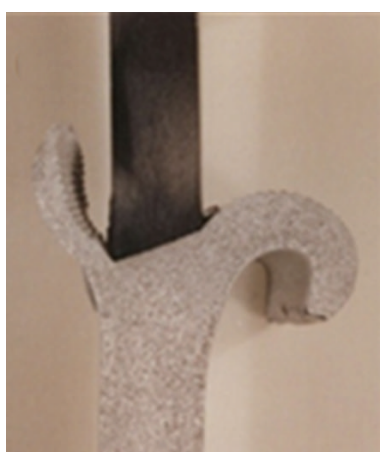

(c)

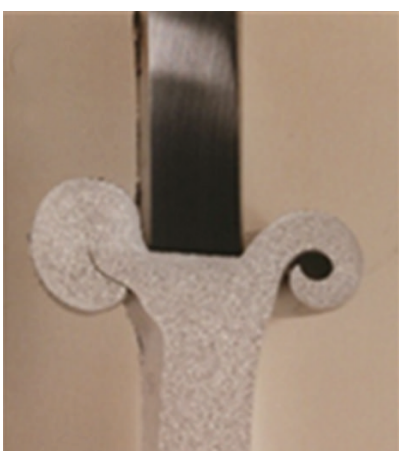

(d)

FIGURE 12: The view of a macrostructure of the pipe walls with a diameter of $50 \mathrm{~mm}$, thickness of the wall of $10 \mathrm{~mm}$, from the friction welded AlMg3 aluminium alloy-X10CrNiTi189 austenitic steel joints, at various methods of forming the joints, with a mandrel, limiting the flash inside the pipe. The beven angle of the steel sample $-10^{\circ}$, rough turned surface (a), with $45^{\circ}$ beven angle and with a lock (b), beven angle of the steel sample $-30^{\circ}$, rough turned surface (c), beven angle of the steel sample $-10^{\circ}$, but to the inside of the pipe, rough turned surface (d).

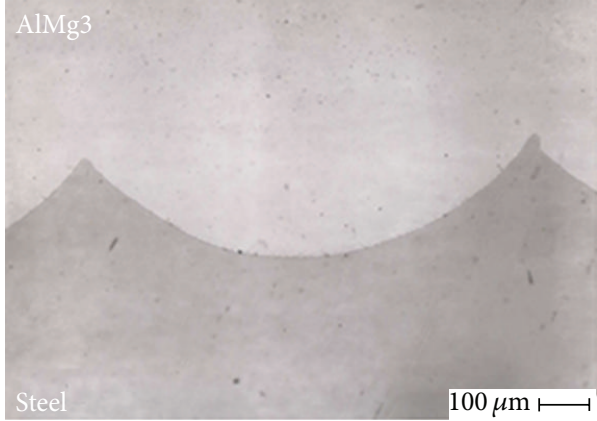

(a)

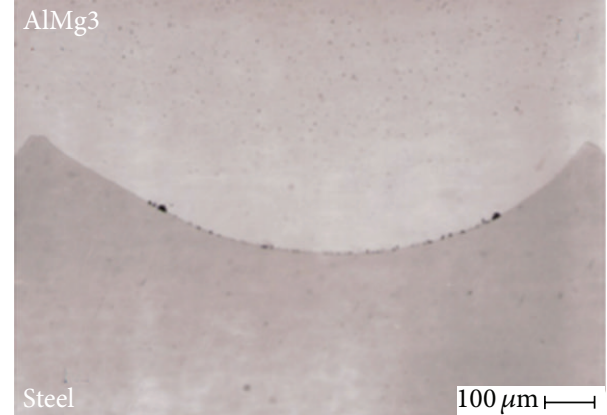

(b)

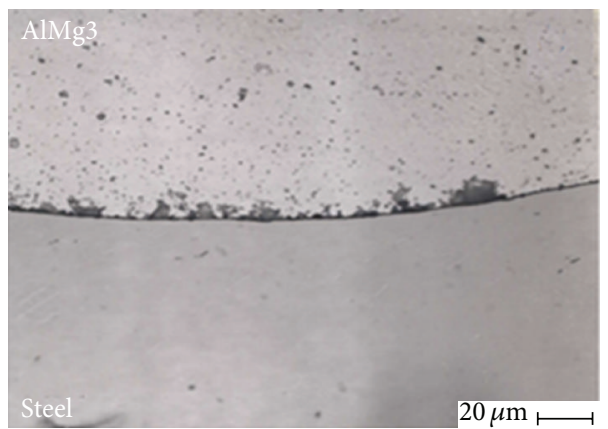

(c)

FIGURE 13: The view of a bond zone of friction welded AlMg3 aluminium alloy-austenitic steel joints (light microscope, nonetched specimen, sample no. 2 (a), sample no. 3 (b), and an enlarged fragment of the b (c) (according to [26])). 


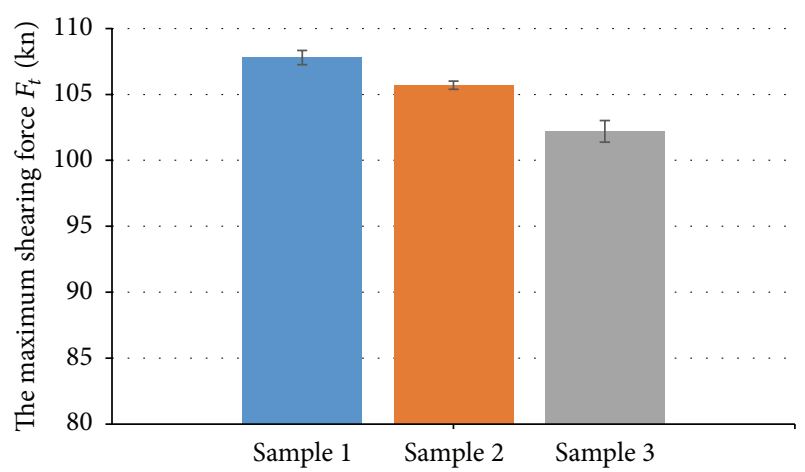

FIGURE 14: The maximum shearing force of the AlMg3 aluminium alloy-X10CrNiTi189 austenitic steel joint (according to [26]).

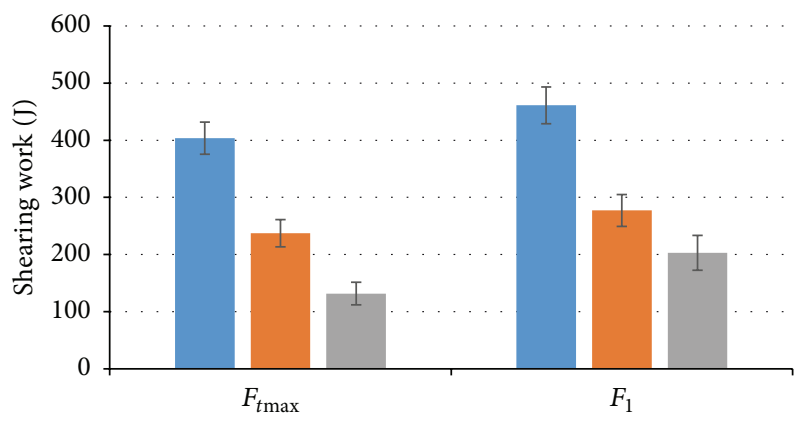

- Sample 1

- Sample 2

- Sample 3

FIGURE 15: The results of shearing work of the investigated AlMg3 aluminium alloy-X10CrNiTi189, austenitic steel joints, determined for two variants of shearing pattern (according to [26]).

lower of $8 \mathrm{kN}$ from the $F_{t \max }$, then the shearing work has average values, respectively, for $461 \mathrm{~J} ; 270 \mathrm{~J}$; and $198 \mathrm{~J}$ (Figure 15).

Comparing the shearing work and the calculated surface area of the aluminium deposition on steel (after the shearing test) has allowed to observe the dependence for increasing the shearing, together with increasing the surface covered with aluminium (Figure 17).

The performed shearing tests of AlMg3 aluminium alloyaustenitic steel joints have allowed stating that the differences in the maximum shearing force of joints formed with various welding parameters were only slight, but the shearing work was different for the joints formed with investigated diversified technological parameters, and could be an important indicator of the joints' quality.

However, it should be noted that the thickness of the intermetallic phases in the friction welded AlMg3 aluminium alloy-X10CrNiTi189 austenitic steel joints was significantly lower (about $1-3 \mu \mathrm{m}$ ) than the one occurring in the diffusion welding $(6-8 \mu \mathrm{m})[29,30]$. For this reason, the friction welded AlMg3 aluminium alloy-X10CrNiTi189 austenitic steel joint can successfully replace the joints formed with diffusion welding.

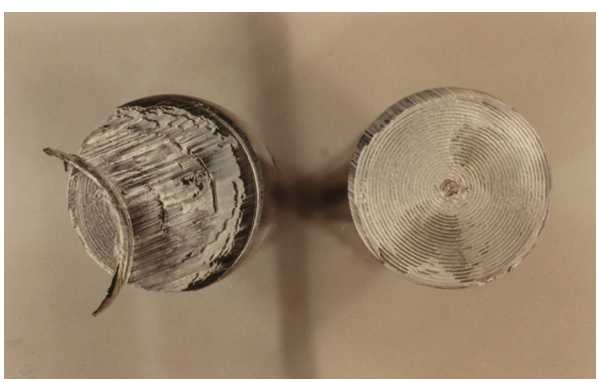

FIGURE 16: The surface of the AlMg3 aluminium alloy-X10CrNiTi189 austenitic steel joint, after the shearing test (parameter no. 1) (according to [26]).

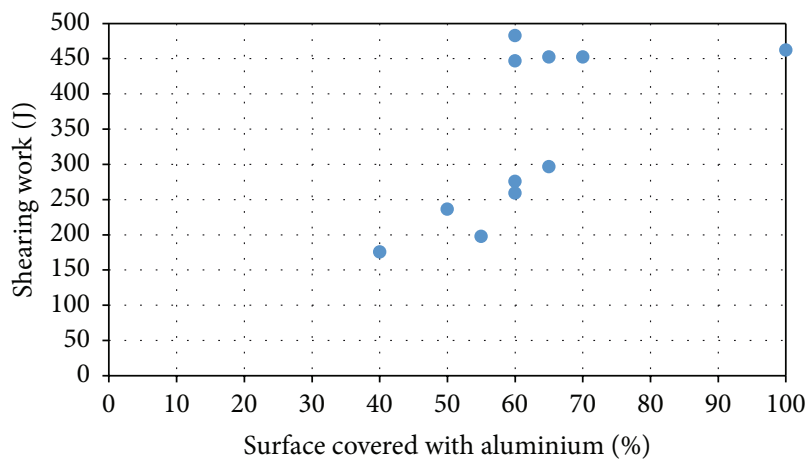

FIGURE 17: The comparison of shearing work of the friction welded AlMg3 aluminium alloy-austenitic steel joints and the surface area of the aluminium sediment on steel (according to [26]).

Towards failures in obtaining the joints with good plastic properties, by direct friction welding of AlMg3 alloy and X10CrNiTil89 steel, further attempts to improve the joint's plastic properties by using the interlayers, formed also with the friction welding method, which is what has been presented in Figure 18, have been conducted.

In the author's first research [13], an Al99.8 pure aluminium interlayer has been used. The obtained joints have been characterized by a tensile strength of $90-185 \mathrm{MPa}$, depending on the thickness of the interlayer, which has been studied in a range of 3-35 $\mathrm{mm}$ (sample no. 4; Table 1 ).

The technological bending test has caused a strong deformation in the pure aluminium interlayer (Figures 19(b) and 19(c)).

Another material, which has been tested as an interlayer for the joints of AlMg3 alloy-X10CrNiTi189 steel, was titanium. As it was presented in chapter 2.2, in the zone of the friction welded titanium-AlMg3 joint, there was a diffusion layer, whose thickness (up to about $10 \mu \mathrm{m}$ ) has depended on the process parameters. It has been stated that the maximum hardness in the diffusion layer was 222 HV 0.005 and was only slightly higher than the microhardness of titanium $(171 \mathrm{HV}$ 0.025).

Since the earlier literature data said that it is not possible to get the joints of titanium-steel, without a layer of brittle intermetallic phases $[27,31]$, it has been decided to combine AlMg3 alloy with X10CrNiTi189 steel and apply a second 


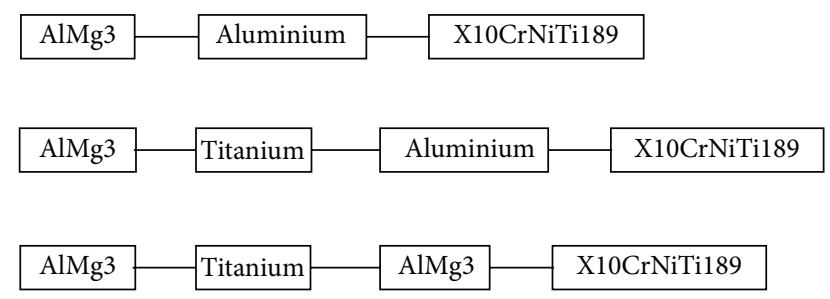

FIGURE 18: The scheme of forming the AlMg3 aluminium alloyX10CrNiTi189 austenitic steel joint, with interlayers.

interlayer, that is, the layer between the steel and the titanium (Figure 18). For the material of this layer the pure Al99.8 aluminium or the AlMg3 alloy has been used. When forming the joints with pure aluminium, the tensile strength has been equal to $185 \mathrm{MPa}$, and the fracture has occurred at the bound of the aluminium-steel bond. The technological bending test has proved the strong deformation at the aluminium layer.

Using the AlMg3 alloy, as a second layer, has allowed to obtain joints with a strength of $346 \mathrm{MPa}$ (the fracture at the AlMg3-steel bound) and to achieve the bending angle of more than $120^{\circ}$ in the technological bending test. Such behaviour may be caused that despite forming the intermetallic phases on the bound of AlMg3 alloy-X10CrNiTi189 steel, the low thickness of the whole additional interlayer allowed stress transfer occurring in the joint during bending. The deformation was observed behind the titanium layer on the AlMg3 side (Figure 20(c)).

Thus, using the titanium and AlMg3 interlayer in the AlMg3 alloy-X10CrNiTi189 austenitic steel joints has enabled to achieve a joint characterized by high strength and relatively high bending angle.

2.2.3. CrMo4 Steel-AlCuMgNi Aluminium Alloy. In the dissertation [14], the author has presented part of the investigations on the friction welding of the $\mathrm{AlCuMgNi}$ aluminium alloy (according to ASTM B247), under the trade name of AN40 as forgings in a T6 supply state (supersaturated and then artificially aged), with steel for quenching and tempering, grade $42 \mathrm{CrMo} 4$ in the form of round bars with a diameter of $45 \mathrm{~mm}$. Using of such high diameters of the samples has been determined by the desire to achieve the most accurate approximation of the research for their utilitarian purpose. Such joint was supposed to replace the previous mechanical bonding of the shaft and rotor, produced from these materials and used in some types of turbo boost in large turbo diesel engines.

Toughening steel (42CrMo4), whose chemical compound has been presented in Table 2, after the austenitization in the temperature of about $850^{\circ} \mathrm{C}$, depending on the cooling rate, might be characterized by various microstructures, with a hardness of $175 \mathrm{HV}-640 \mathrm{HV}$. The drawing temperature for steel was $480-650^{\circ} \mathrm{C}$ and the soft annealing temperature was $680-720^{\circ} \mathrm{C}$.

The surfaces of the samples for friction welding have been prepared with turning and washed in ethyl alcohol, directly before welding. The samples of aluminium alloy have been additionally etched and then washed in ethyl alcohol again. The front surfaces of the steel samples have been joined at an angle of inclination of $2^{\circ}$ to the axis, in order to reduce the initial friction moment.

In the first stage of the researches on the AN40-steel $42 \mathrm{CrMo} 4$ joints, the researchers have decided to perform the friction welding on the joints, using the parameters presented in Table 1 (sample no. 5). To differentiate the amount of supplied heat various parameters including two rotational speed values have been selected (720 and $1500 \mathrm{~min}^{-1}$ ).

The results of the metallographic examinations have proved that supplying higher amount of energy in the welding process has caused an occurrence of a cracked diffusion layer with a microhardness of $516 \mathrm{HV}$ (Figure 21), which resulted in the destruction of joints in a tensile test at very low load. The use of a shorter welding time, but higher pressure, has led to disappearance of the diffusion layer, but the joint's strength has been still slight (about $100 \mathrm{MPa}$ ). The researchers' conduct in this stage has shown that a little higher strength was a feature of joints that have been formed at lower rotational speed.

There have been attempts of increasing the diffusion interaction on the surface of the AN40-42CrMo4 steel joint, by additional annealing of the joint in the diffusion welder. The researches have shown that for a wide range of welding parameters, it was possible to obtain an increase of the joints' strength, but also the achieved results were unsatisfactory.

Thus, as a result of the conducted researches, it has been stated that by the direct friction welding of $42 \mathrm{CrMo} 4$ steel and AN40 aluminium alloy, the mechanical properties of the joints were low (tensile strength up to $100 \mathrm{MPa}$ ). An occurrence of a narrow diffusion layer at the joining bound has been stated too. The use of various friction welding parameters, resulting in supplying into the joint a lower amount of heat, has caused not only a disappearance of the diffusion zone, but also a decrease of the joint's strength.

Further attempts have been taken to obtain better properties of the $42 \mathrm{CrMo} 4$ steel-AN40 aluminium alloy joint, by using some interlayers, formed with friction welding too.

At this stage, the researchers have decided to use an interlayer, produced from metal, that would have a greater range of forming the solid solution of aluminium, and thus the intermetallic phases' zone should not be formed so quickly in the bonding zone, as it was for direct bonding of $42 \mathrm{CrMo} 4$ steel and AN40 alloy. The analysis, of the dual systems from aluminium, has allowed the assumption that none of metals have not formed concentration of the solid solution without intermetallic phases in the whole range. On the base of the previous researches on the diffusion welding process $[29,30]$, the nickel has been selected.

Thus, the round bars made of $42 \mathrm{CrMo} 4$ steel have been friction welded with the nickel plates with dimensions of $2 \times$ $50 \times 50 \mathrm{~mm}$, (sample no. 6; Table 1), and then the front surface and nickel/steel joint's side surface have been turned. Such prepared intermediate products were subsequently welded with an AN40 aluminium alloy (sample no. 7; Table 1). The first attempts have allowed obtaining the joints with the strength of 211-235 MPa. 


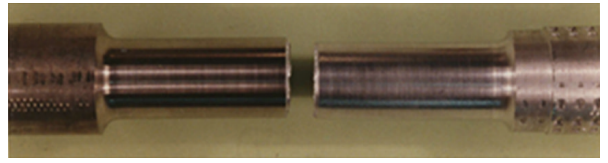

(a)

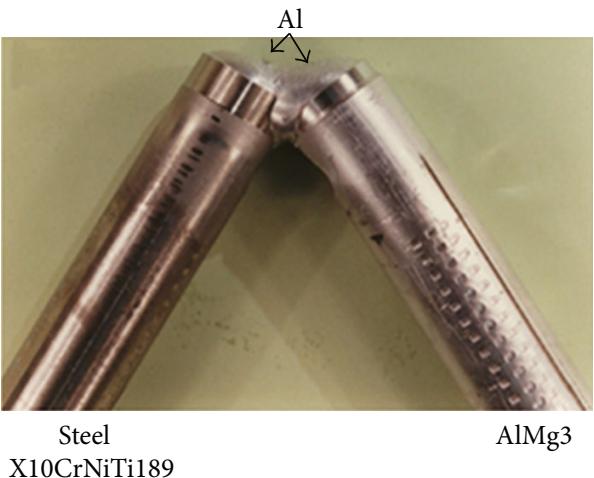

(b)

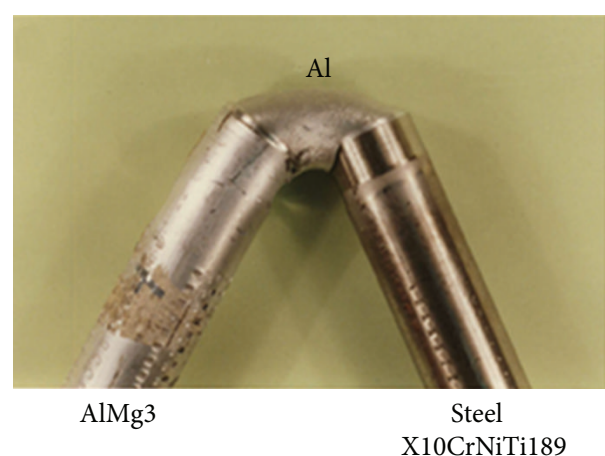

(c)

FIgURE 19: The view of a AlMg3 aluminium alloy-X10CrNiTi189 steel joint with an interlayer, with an addition of Al99,8 aluminium (thickness $8 \mathrm{~mm}$ ) after the static tensile test (a), after the technological bending test (b), and after the technological bending test at the aluminium interlayer with a thickness of $18 \mathrm{~mm}$ (c) (according to [13]).

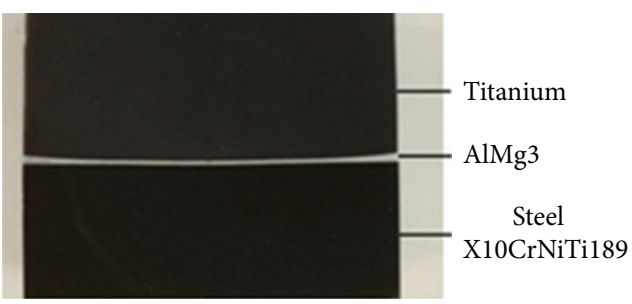

(a)

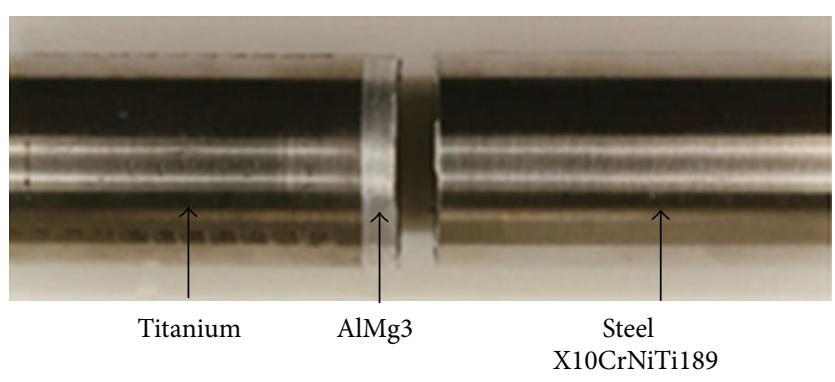

(b)

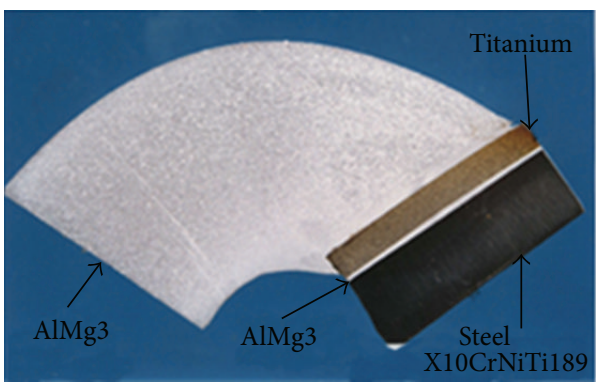

(c)

Figure 20: The view of a macrostructure of a friction welded titanium-AlMg3-X10CrNiTi189 joint (a), a joint after the tensile test (b), and an AlMg3-titanium-AlMg3-X10CrNiTi189 joint after the technological bending test (c) (according to [13]).

TABLE 2: The chemical compound of the tested materials (according to [14]).

\begin{tabular}{|c|c|c|c|c|c|c|c|c|c|c|c|c|c|}
\hline \multirow{2}{*}{ Material } & \multicolumn{13}{|c|}{ Content, wt $\%$} \\
\hline & & $\mathrm{C}$ & $\mathrm{Cu}$ & Mo & $\mathrm{Si}$ & $\mathrm{Mn}$ & $\mathrm{Mg}$ & $\mathrm{Cr}$ & $\mathrm{Ni}$ & $\mathrm{Ti}$ & $\mathrm{Zn}$ & Otl & \\
\hline \multirow{2}{*}{$\begin{array}{l}\text { AlCuMgNi } \\
\text { (acc. to ASTM B247) }\end{array}$} & $\min$. & 0.9 & 2.3 & \multirow[t]{2}{*}{-} & 0.2 & - & 1.4 & - & 0.9 & - & - & 0.05 & \multirow{2}{*}{$\mathrm{Al}$-the rest } \\
\hline & $\max$. & 1.2 & 2.7 & & 0.25 & 0.10 & 1.8 & 0.05 & 1.2 & 0.06 & 0.1 & 0.15 & \\
\hline \multirow{2}{*}{$\begin{array}{l}\text { 42CrMo4 } \\
\text { (acc. to DIN 17200) }\end{array}$} & $\min$. & 0.38 & \multirow{2}{*}{-} & 0.15 & - & 0.50 & \multirow{2}{*}{ - } & 0.90 & \multirow{2}{*}{ - } & \multirow{2}{*}{-} & \multirow{2}{*}{ - } & $P$-max. 0.035 & \multirow[t]{2}{*}{$\mathrm{Fe}$-the rest } \\
\hline & $\max$ & 0.45 & & 0.30 & 0.40 & 0.80 & & 1.20 & & & & $S-\max .0 .030$ & \\
\hline
\end{tabular}




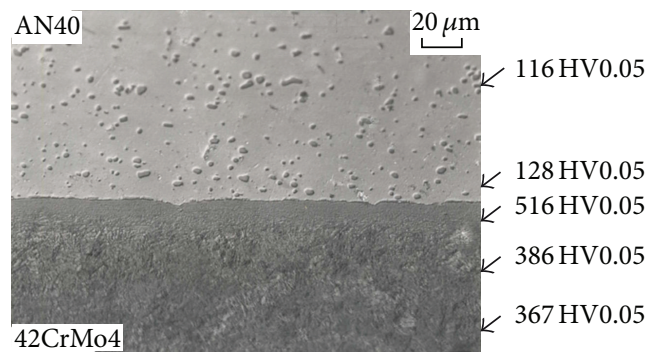

FIGURE 21: The microstructure of the friction welded AN40 alloy-42CrMo4 steel joint.

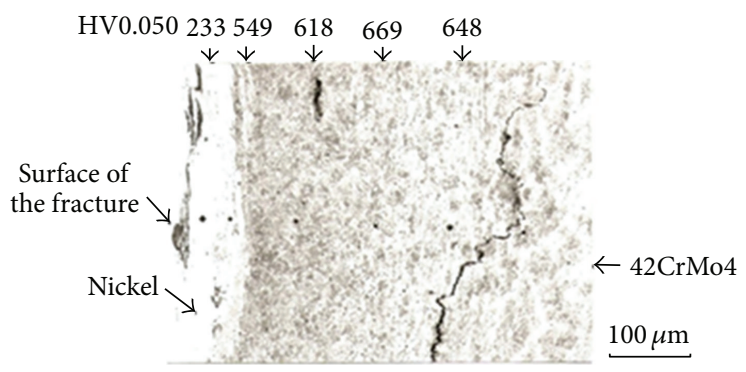

(a)

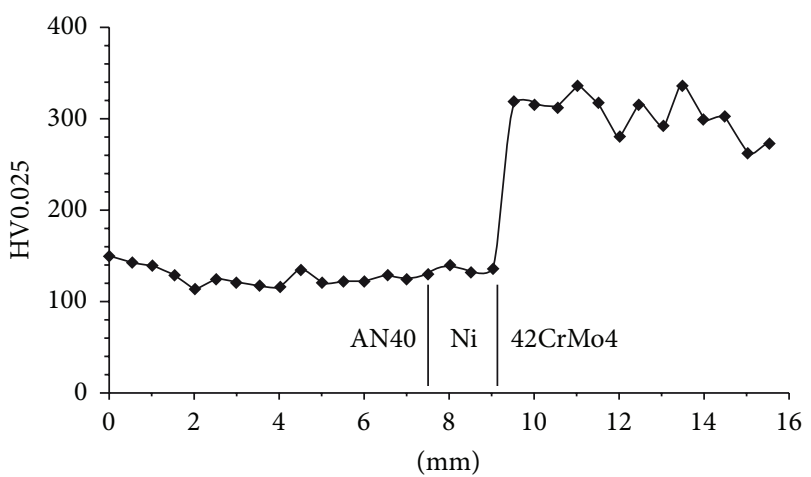

(b)

Figure 22: The friction welded 42CrMo4 steel-AN40 alloy joints, microstructure after the tensile test (a), and a microhardness pattern (b) (according to [14]).

Further researches have been concerned with a proper preparing of the nickel surface. It has turned out that the rough turning of the front surfaced at the nickel side, instead of an accurate turning, has increased the strength of the joint. It has been stated that the advantageous results were achieved for the front surface with the roughness parameter equal to $R_{a}=43 \mu \mathrm{m}, R_{z}=162 \mu \mathrm{m}$. The performed attempts of additional soaking in a vacuum oven, to produce a wider diffusion layer on the bonding surface, have not resulted in the increase of the joint's tensile strength.

The metallographic researches have proved that after the friction welding of $42 \mathrm{CrMo} 4$ steel and nickel, on the steel side, a zone with quenching structures and a microhardness of $648 \mathrm{HV} 0.050$ has occurred, when the microhardness of the base material was $310 \mathrm{HV} 0.050$ (Figure 22). In the joints, after the tensile test, some microcracks in this zone have been observed, despite the fact that the fracture of the sample has occurred in the AN40-Ni bonding.

To remove the zone with high hardness in steel, the friction welded $42 \mathrm{CrMo} 4$ steel-nickel joint has been heat treated $\left(680^{\circ} \mathrm{C}, 60\right.$ minutes, vacuum oven). After such annealing, the next stage of the friction welding has been performed, that is, the AN40 alloy-Ni/42CrMo4 steel joint. The temperatures occurring on the bound of the aluminium alloy-nickel/42CrMo4 steel joint have not caused the austenitization in steel, so the quenching structures were not formed, unlike for welding with materials with higher melting temperatures. The results of the investigations on the microhardness of such joints are shown in Figure 22. It shows that the heat treatment has caused a disappearance of the hard zone on the steel side (microhardness of steel at the contact zone has reached about $330 \mathrm{HV}$ ).

The most advantageous mechanical properties of the joint-tensile strength of about $270 \mathrm{MPa}$ (which is about $70 \%$ of tensile strength for AN40 alloy) have been obtained for the joint formed with the following steps: steel-nickel friction welding, heat treatment (high-temperature tempering), and one another friction welding of the achieved steel-nickel joint with aluminium alloy. The view of the joint after the friction welding is presented in Figure 23(a), and the view of the joint after removal of the flash with a visible interlayer from nickel can be seen in Figure 23(b). The microstructure of the joint is shown in Figure 24. On the contact surface of AN40 alloy-nickel, on both sides, there was a visible discontinuous intermetallic phase separation (Figure 24(b)).

The fracture during the tensile test has occurred on the surface of the nickel-aluminium alloy joint. Due to achieving the marginal pressure force values in the device for friction welding (about $400 \mathrm{kN}$ ), it has not been possible to use higher upsetting pressure, at samples with a diameter of $45 \mathrm{~mm}$, which would allow improving the mechanical properties of the joint.

There is also a possibility to bond aluminium and steel or aluminium alloys, with the friction stir welding method (FSW) [32, 33]. In the dissertation [34], some examples of welding the AA6061 aluminium alloys with SS400 low carbon 


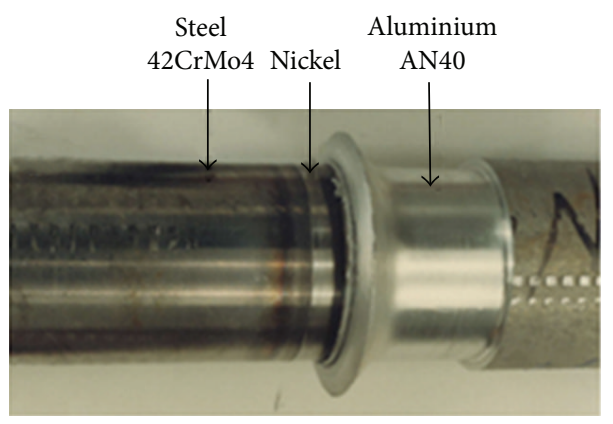

(a)

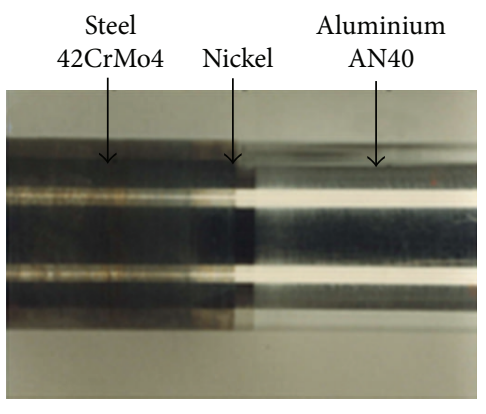

(b)

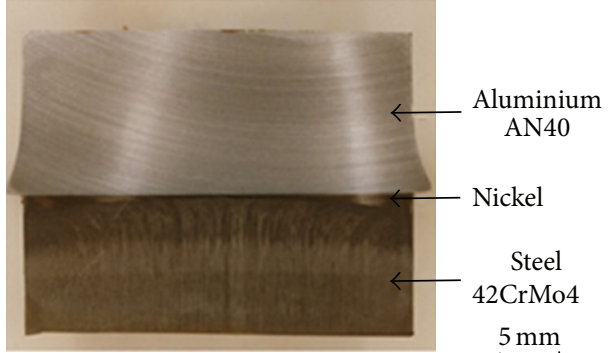

(c)

Figure 23: The view of the joint after the friction welding of 42CrMo4 steel-AN40 alloy with nickel interlayer, directly after the welding (a), after removal of the flash (b), and the macrostructure of the joint (c).

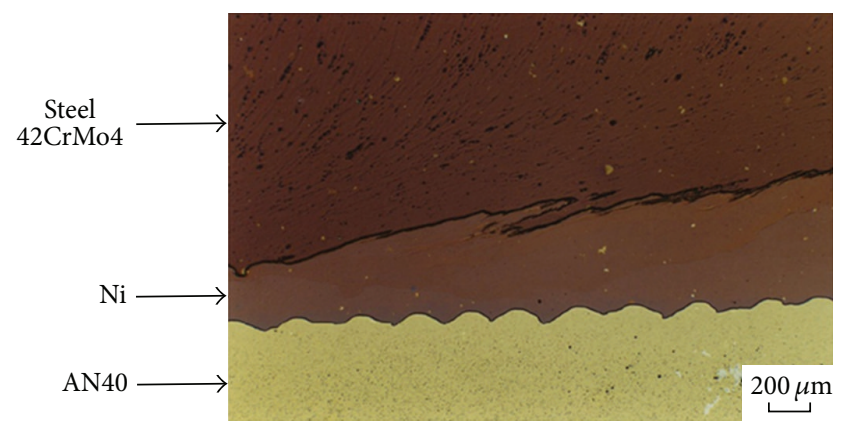

(a)

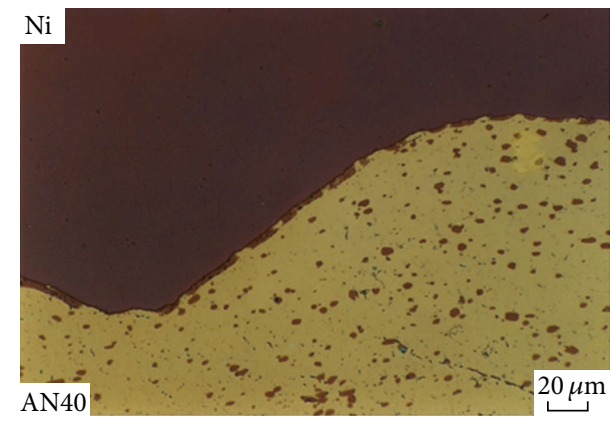

(b)

Figure 24: The microstructure of the 42CrMo4 steel-AN40 alloy joint with the nickel interlayer (a) and a fragment of an enlarged microstructure of the nickel-AN40 alloy bounding zone (b).

steel were presented. The authors have used the analysis of variance and other techniques of statistic methods, for the interpretation of the experiment's results. The joints have been formed with two different values of the rotational speed of the device $\left(550 \mathrm{~min}^{-1}\right.$ and $\left.800 \mathrm{~min}^{-1}\right)$ and three values of the feed speed $\left(0.9 ; 1.2\right.$; and $\left.1.5 \mathrm{~mm} \cdot \mathrm{s}^{-1}\right)$. It has been stated that the lowest fracture work has reached $36 \mathrm{~J}$ and has occurred for the joints formed with the lowest of the investigated rotational speed values of the device $\left(550 \mathrm{~min}^{-1}\right)$.

The results of the butt welding of X5CrNi1810 austenitic steel and $\mathrm{Al} 6013$ aluminium alloy were presented in [35]. The microscopic observations have proved an inhomogeneous layout of the deformed particles of stainless steel with irregular shapes surrounded by a matrix of aluminium alloy. In some of the particles of steel, which have been in the closure weld, microcracks have occurred. This has been explained as a result of high degree of deformation and an intensive mixing of the materials. The endurance limit of the joint has been about 30\% lower than the endurance limit of the aluminium alloy.

\section{Conclusion}

The different research issues that can occur during friction welding of dissimilar materials were described in this paper.
The structural effects during welding, mechanical properties of joints, and different configurations of the process in order to obtain high-quality welds were analyzed.

The analysis of the aluminium-iron dual system leads to the conclusion that long time and high temperatures of the process can cause the formation of intermetallic phases. They are likely to be the reason for brittleness of joints. Depending on the type of joined materials and the process parameters different metal compounds having different properties may be formed.

During the friction welding of pure aluminum with austenitic steel intermetallic phases are formed, but the mechanical properties of the joints (strength and the plasticity) are still good and breaking occurs on the aluminum side.

In the industry, especially in marine, aviation, and refrigeration industries, the joints of aluminium alloys and chromium-nickel austenitic steel are applicable. But the alloying additions, which are present in aluminium alloys (especially magnesium), usually aggravate the metallurgic conditions of aluminium bonding. They cause acceleration of the formation of the intermetallic phases at the joint's boundary, because of the increase of the diffusion coefficient. Numerous attempts to reduce the number of brittle compounds in the transition zone associated with the selection of process parameters or changing the geometry of bonding's surface did not bring the expected results. The way to obtain 
good plastic properties in this kind of joint is the use of different kinds of interlayers, for example, titanium, nickel, aluminium, or mixed as titanium-aluminium interlayers. Moreover if the steel has a tendency to create the quenching structures it is possible to remove the zone with high hardness in steel with the use of heat treatment.

\section{Nomenclature}

$\begin{array}{ll}p_{t 1} / p_{t 2}: & \text { Friction pressure }(\mathrm{MPa}) \\ t_{t 1} / t_{t 2}: & \text { Friction time }(\mathrm{s}) \\ p_{s}: & \text { Upsetting pressure }(\mathrm{MPa}) \\ s_{t} / s: & \text { Shortening }(\mathrm{mm}) \\ R_{m}: & \text { Minimum ultimate tensile strength }(\mathrm{MPa}) \\ R_{z}: & \text { Roughness parameter (ten-point height) } \\ & (\mu \mathrm{m}) \\ R_{a}: & \text { Roughness parameter (arithmetic average } \\ & \text { height) }(\mu \mathrm{m}) \\ F_{t \text { max }}: & \text { Maximum shearing work }(\mathrm{kN}) \\ F_{1}: & \text { Shearing work }(\mathrm{kN}) .\end{array}$

\section{Conflict of Interests}

The authors declare that there is no conflict of interests regarding the publication of this paper.

\section{References}

[1] P. D. Sketchley, P. L. Threadgill, and I. G. Wright, "Rotary friction welding of an Fe3Al based ODS alloy," Materials Science and Engineering A, vol. 329-331, pp. 756-762, 2002.

[2] I. Bhamji, M. Preuss, P. L. Threadgill, and A. C. Addison, "Solid state joining of metals by linear friction welding: a literature review," Materials Science and Technology, vol. 27, no. 1, pp. 2-12, 2011.

[3] N. Alberti and L. Fratini, "Friction stir welding: a solid state joining process," Advanced Manufacturing Systems and Technology, vol. 486, pp. 67-86, 2005.

[4] M. Sahin, "Friction welding of different materials," in International Scientific Conference, pp. 19-20, Gabrovo, Bulgaria, November 2010.

[5] R. N. Shubhavardhan and S. Surendran, "Friction welding to join dissimilar metals," International Journal of Emerging Technology and Advanced Engineering, vol. 2, no. 7, 2012.

[6] M. Sahin, "Joining of stainless-steel and aluminium materials by friction welding," International Journal of Advanced Manufacturing Technology, vol. 41, no. 5-6, pp. 487-497, 2009.

[7] H. Ochi, K. Ogawa, Y. Yamamoto, and Y. Suga, "Friction welding of aluminum alloy and steel," International Journal of Offshore and Polar Engineering, vol. 8, no. 2, pp. 140-143, 1998.

[8] S. Sundaresan and K. G. K. Murti, "Formation of intermetallic phases in aluminium-austenitic stainless steel friction welds," Metals Forum, vol. 17, no. 3, pp. 301-307, 1994.

[9] S. Fukumoto, H. Tsubakino, K. Okita, M. Aritoshi, and T. Tomita, "Microstructure of friction weld interface of 1050 aluminium to austenitic stainless steel," Materials Science and Technology, vol. 14, no. 4, pp. 333-338, 1998.

[10] H. Seli, A. I. M. Ismail, E. Rachman, and Z. A. Ahmad, "Mechanical evaluation and thermal modelling of friction welding of mild steel and aluminium," Journal of Materials Processing Technology, vol. 210, no. 9, pp. 1209-1216, 2010.

[11] T. J. Jessop, E. D. Nicholas, and W. O. Dinsdale, "Friction welding dissimilar metals. Advances in welding processes," in Proceedings 4th International Conference, pp. 23-36, The Welding Institute, Harrogate, England, 1978.

[12] S. J. NA, Das Reibschweissen Ungleichartiger Metalle, Praca doktorska TU, Braunschweig, Germany, 1983.

[13] A. Ambroziak, Badania Zgrzewanych Tarciowo Złaczy AlMg3Stal Austenityczna, Inżynieria Materiałowa, 2003.

[14] A. Ambroziak, ZgrZewanie Tarciowe Stali 42CrMo4 Ze Stopem Aluminium AlCuMgNi, Energetyka, 2008.

[15] T. B. Massalski, H. Okamoto, P. R. Subramanian, and L. Kacprzak, Binary Alloy Phase Diagrams, ASM International, 2nd edition, 1990.

[16] S. Elliott and E. R. Wallach, "Joining aluminum to steel," Metal Construction, vol. 13, no. 3, pp. 167-171, 1981.

[17] B. S. Yilbaş, A. Z. Şahin, N. Kahraman, and A. Z. Al-Garni, "Friction welding of StAl and $\mathrm{AlCu}$ materials," Journal of Materials Processing Technology, vol. 49, no. 3-4, pp. 431-443, 1995.

[18] A. Ambroziak, Zgrzewanie Tarciowe Materiałów o Różnych Właściwościach, Oficyna Wyd. PWr, Wrocław, Poland, 2011.

[19] J. Senkara and H. Zhang, MechanIzm I CzynnIkI TechnologIczne Wplywajace Na PękanIe Stopu AlMg3 Podczas WIelopunktowego ZgrzewanIa Rezystancyjnego, Przegląd Spawalnictwa, 2006.

[20] V. V. Trutnev and M. H. Šoršonov, DIffuzjonnaja Svarka AustenItnoj StalI S AlumInIem I Jevo SplavamI, 1967.

[21] M. Kikuchi, H. Takeda, and S. Morozumi, "Bonding interfaces in friction- and explosive- welded aluminum and steel joints," Journal of Japan Institute of Light Metals, vol. 34, no. 3, pp. 165173, 1984 .

[22] S. Fukumoto, M. Ohashi, H. Tsubakino et al., "Microstructures of friction welded joint of 6061 aluminum alloy to 304 stainless steel," Journal of Japan Institute of Light Metals, vol. 48, no. 1, pp. 36-41, 1998.

[23] S. Fukumoto, H. Tsubakino, K. Okita, M. Aritoshi, and T. Tomita, "Friction welding process of 5052 aluminium alloy to 304 stainless steel," Materials Science and Technology, vol. 15, no. 9, pp. 1080-1086, 1999.

[24] S. Fukumoto, H. Tsubakino, K. Okita, M. Aritoshi, and T. Tomita, "Amorphization by friction welding between 5052 aluminum alloy and 304 stainless steel," Scripta Materialia, vol. 42, no. 8, pp. 807-812, 2000.

[25] G. Kawai, K. Ogawa, and H. Tokisue, "Friction welding of 6061 aluminum alloy pipe to S25C carbon steel pipe," International Journal of Offshore and Polar Engineering, vol. 8, no. 2, pp. 144147, 1998.

[26] A. Ambroziak, M. Korzeniowski, and M. WINNICKI, Ocena Właściwości Mechanicznych Zgrzewanych Tarciowo Złączy Stop Aluminium EN AW-5754-Stal Austenityczna, Przegląd Spawalnictwa, 2010.

[27] A. Ambroziak, Dobór Warstw Przejściowych Dla Różnoimiennych Złączy Zgrzewanych Tarciowo, Biuletyn Instytutu Spawalnictwa w Gliwicach, 1999.

[28] K. Mechner and H. Klock, Grenzflächengefüge Von Reibschweissverbindungen Aus Aluminium Und Stahl, Aluminium, 1983.

[29] R. Lison, Schweissen Und Löten Von Sondermetallen Und Ihren Legierungen, Düsseldorf, Germany, 1996. 
[30] R. Lison, Wege Zum Stoffschluss Über Schweiß- Und Lötprozesse, Fachbuchreihe Schweißtechnik, 1998.

[31] A. Ambroziak, Zgrzewanie Tarciowe Metali Trudno Topliwych W Cieczy Na Tle Innych Metod Spajania, Oficyna Wyd. PWr, Wrocław, Poland, 1998.

[32] R. S. Mishra and M. W. Mahoney, Friction Stir Welding and Processing, United States of America, ASM International, 2007.

[33] R. S. Mishra, R. K. Islamgaliev, T. W. Nelson, Y. Hovansky, and M. W. Mahoney, "Abnormal grain growth during high temperature exposure in friction stir processed 7050 and 2519 aluminum alloys," in Proceedings of Symposium on Friction Stir Welding and Processing, pp. 205-216, Indianapolis, Ind, USA, November 2001.

[34] T. Chen and W.-B. Lin, "A study on dissimilar FSW process parameters in aluminum alloy and low carbon steel," in International Conference on Smart Manufacturing Application (ICSMA '08), pp. 9-14, Gyeonggi-do, Korea, April 2008.

[35] H. Uzun, C. Dalledonne, A. Argagnotto, T. Ghidini, and C. Gambaro, Friction Stir Welding of Dissimilar Al 6013-T4 To X5CrNi18-10 Stainless Steel, Materials and Design, 2005. 

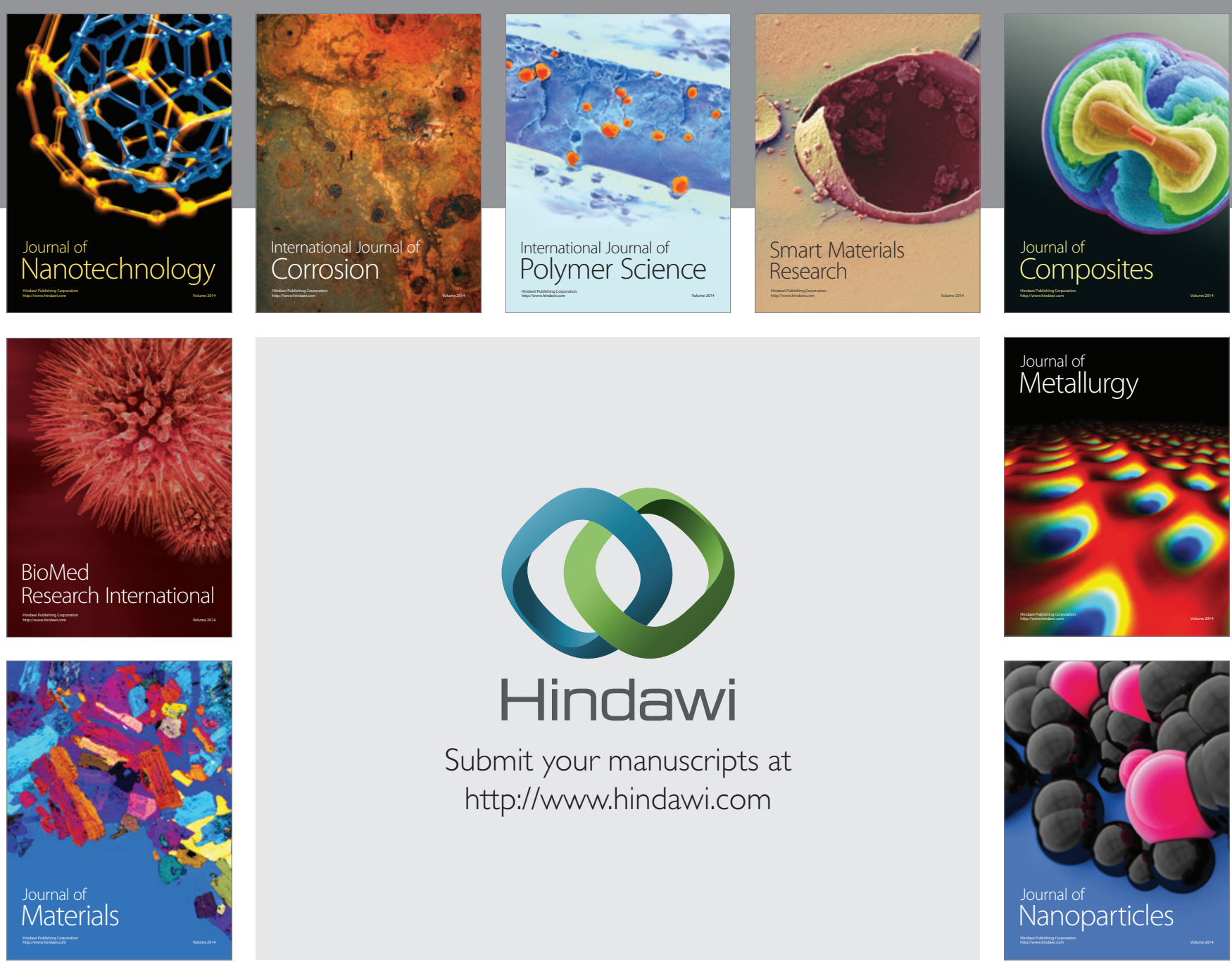

Submit your manuscripts at http://www.hindawi.com
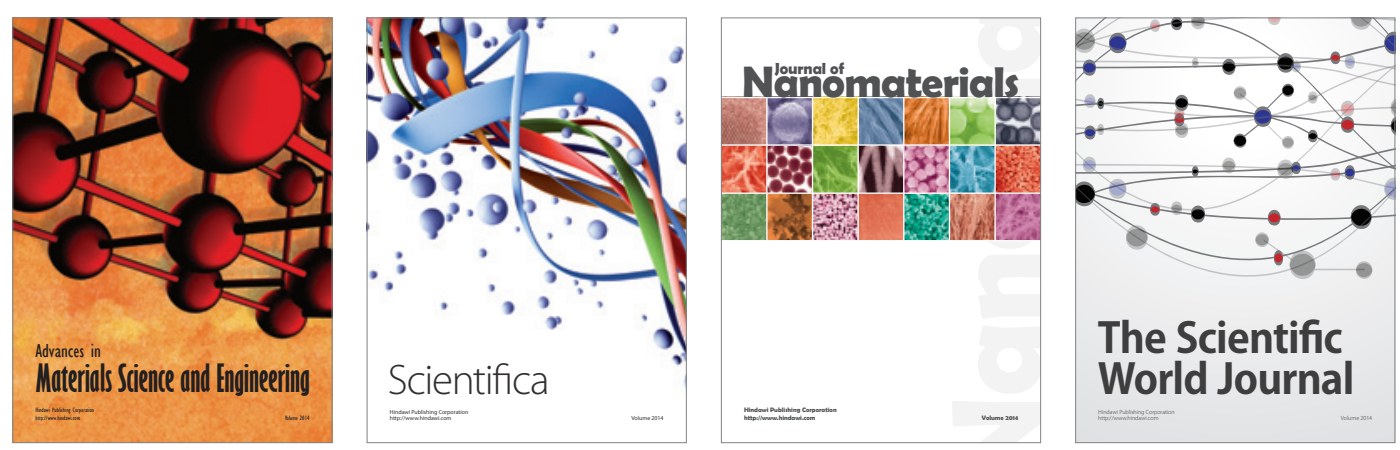

\section{The Scientific World Journal}
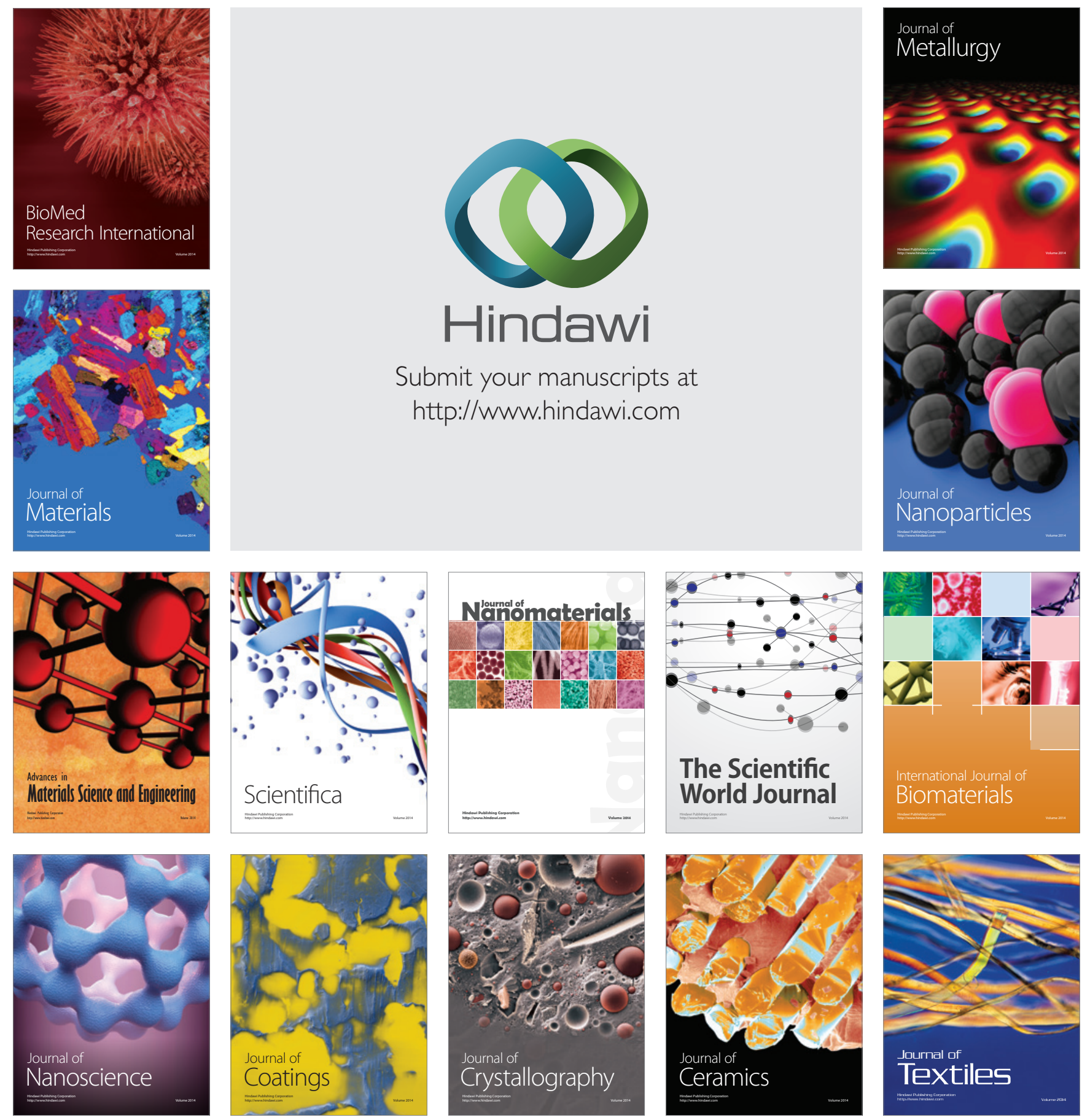